\title{
Canine vegan biscuits produced with inulin and blackberry flour
}

\author{
Biscoitos caninos veganos produzidor com inulina a farinha de amora \\ Productor de galletas caninas veganas con inulina y harina de mora
}

Received: 02/15/2021 | Reviewed: 02/21/2021 |Accept: 02/22/2021 | Published: 02/28/2021

Caroline Mantovani Celegatti ORCID: https://orcid.org/ 0000-0002-2943-9792 State University of Campinas, Brazil E-mail: carolinecelegatti@gmail.com

Thaísa de Menezes Alves Moro ORCID: https://orcid.org/0000-0002-8483-0364 State University of Campinas, Brazil E-mail: thaisamoro@hotmail.com

Aline de Souza Lopes

ORCID: https://orcid.org/0000-0003-3920-6340 State University of Campinas, Brazil

E-mail: alinesl@unicamp.br

Ana Paula Aparecida Pereira

ORCID: https://orcid.org/0000-0002-7206-9707 Federal University of Mato Grosso, Brazil E-mail: pereira.anap23@gmail.com

Glaucia Maria Pastore

ORCID: https://orcid.org/0000-0001-9631-0158 State University of Campinas, Brazil E-mail: glaupast@fea.unicamp.br

Pedro H. Campelo

ORCID: https://orcid.org/0000-0002-5137-0162 Federal University of Amazonas, Brazil E-mail: pedrocampelo@ufam.edu.br

Maria Teresa Pedrosa Silva Clerici

ORCID: https://orcid.org/0000-0002-8445-336X State University of Campinas, Brazil E-mail: mclerici@unicamp.br

\begin{abstract}
Pet food accounts for more than $60 \%$ of the total sales in the pet market, with emphasis on products with the addition of functional ingredients and health claims. The objective of the present study was to manufacture vegan canine biscuits, as snacks, containing the following functional ingredients: inulin, blackberry flour (BBF), and hydrolyzed soy protein (HSP). Four formulations were made, as follows: CB1, a control formulation, without the addition of inulin, BBF, and HSP. For the other formulations, the amount of BBF and HSP was set at 50 and $35 \mathrm{~g} / \mathrm{kg}$, respectively, and the inulin contents were 30,60 , and $90 \mathrm{~g} / \mathrm{kg}$, for the formulations CB2, CB3, and CB4, respectively. All biscuits were evaluated for their technological properties. The increase in inulin significantly reduced the hardness of the biscuits from $30 \mathrm{~N}$ (CB1) to $20 \mathrm{~N}$ (CB3 and CB4). The biscuits with blackberry exhibited a pink color, which shows that this natural ingredient can be used as a food coloring ingredient, thus avoiding the use of synthetic additives. CB3 and CB4 had the same acceptance as CB1, indicating no sensory rejection of the ingredients by the dogs. The BBF increased (pvalue $<0.05$ ) the total phenolics content and the antioxidant capacity, and inulin increased ( $p$-value $<0.05$ ) the prebiotic activity in relation to the control. The study demonstrated that color-conferring ingredients with bioactive compounds can be used in canine biscuits formulations, with no changes in the sensory acceptance, which can be an effective alternative to include the functional ingredients while maintaining the health appeal and clean label of the products.
\end{abstract}

Keywords: Pet food; Veganism; Canine snack; Dogs; Oligosaccharide.

\section{Resumo}

Os alimentos para animais de estimação respondem por mais de $60 \%$ das vendas totais do mercado pet, com destaque para produtos com adição de ingredientes funcionais e alegações de saúde. O objetivo do presente estudo foi produzir biscoitos caninos veganos, como snacks, contendo os seguintes ingredientes funcionais: inulina, farinha de amora silvestre (BBF) e proteína hidrolisada de soja (HSP). Foram feitas quatro formulações: CB1, uma formulação controle, sem adição de inulina, BBF e HSP. Para as outras formulações, a quantidade de BBF e HSP foi fixada em 50 e $35 \mathrm{~g} / \mathrm{kg}$, respectivamente, e os teores de inulina foram 30, 60 e $90 \mathrm{~g} / \mathrm{kg}$, para as formulações CB2, CB3 e CB4, respectivamente. Todos os biscoitos foram avaliados quanto às suas propriedades tecnológicas. $\mathrm{O}$ aumento da inulina reduziu 
significativamente a dureza dos biscoitos de $30 \mathrm{~N}$ (CB1) para $20 \mathrm{~N}$ (CB3 e CB4). Os biscoitos com amora exibiram uma coloração rosada, o que mostra que esse ingrediente natural pode ser utilizado como corante alimentar, evitando assim o uso de aditivos sintéticos. CB3 e CB4 tiveram a mesma aceitação que CB1, indicando que não houve rejeição sensorial dos ingredientes pelos cães. $\mathrm{O}$ BBF aumentou (p-valor<0,05) o teor de fenólicos totais e a capacidade antioxidante, e a inulina aumentou ( $\mathrm{p}$-valor $<0,05)$ a atividade prebiótica em relação ao controle. $\mathrm{O}$ estudo demonstrou que ingredientes que conferem cor com compostos bioativos podem ser usados em formulações de biscoitos caninos, sem alterações na aceitação sensorial, o que pode ser uma alternativa eficaz para incluir os ingredientes funcionais, mantendo o apelo à saúde e o rótulo limpo dos produtos.

Palavras-chave: Comida para animais domésticos; Veganismo; Snack caninos; Cachorro; Oligossacarídeos.

\section{Resumen}

Los alimentos para mascotas abarcan más del $60 \%$ de las ventas totales del mercado pet, destacándose los productos con adición de ingredientes funcionales y beneficios a la salud. El objetivo del presente estudios fue producir galletas veganas para caninos, como snacks, conteniendo los siguientes ingredientes funcionales: inulina, harina de zarzamora (BBF) y proteína aislada de soya (HSP). Se realizaron cuatro formulaciones: CB1, una formulación control sin adición de inulina, BBF y HSP. En las otras formulaciones, la cantidad de BBF y HSP fue fijada en $50 \mathrm{y} 35 \mathrm{~g} / \mathrm{kg}$, respectivamente, y los contenidos de inulina fueron 30, 60 y $90 \mathrm{~g} / \mathrm{kg}$, para las formulaciones CB2, CB3 y CB4, respectivamente. Se evaluaron las propiedades tecnológicas de todos los productos. El aumento de la inulina redujo significativamente la dureza de las galletas de 30N (CB1) a 20N (CB3 y CB4). Las galletas con zarzamora presentaron una coloración rosada, lo que demuestra que este ingrediente natural puede ser utilizado como colorante alimenticio, evitando así el uso de aditivos sintéticos. CB3 y CB4 tuvieron la misma aceptación que CB1, lo que indica que no hubo rechazo sensorial de los ingredientes por parte de los canes. La BBF aumentó (p-valor<0.05) el contenido de fenólicos totales y la capacidad antioxidante, mientras que la inulina aumentó (p-valor $<0.05$ ) la actividad prebiótica en comparación al control. El estudio demostró los ingredientes que confieren color con compuestos bioactivos pueden ser utilizados para la formulación de galletas caninas, sin alterar la aceptación sensorial, lo que puede ser una alterativa eficaz para incluir ingredientes funcionales, manteniendo el enfoque em la salud y la etiqueta limpia de los productos.

Palabras clave: Comida para animales domésticos; Veganismo; Snacks caninos; Cachorro, Oligosacáridos.

\section{Introduction}

The estimated number of pets in the world is 1.6 billion, and approximately 360 million correspond to the population of dogs. Brazil maintains the 4th position in the world ranking, with 132 million pets, and 52 million dogs. In the pet product market, more than $60 \%$ of sales correspond to the feeding of dogs, cats, fish, birds, and reptiles, with a turnover above US\$ 50 million by 2016 (ABINPET, 2016).

Pet food industries have developed new products and formulas to fuel the pet food market. From January 2013 to October 2014, more than 4000 snacks and 6000 canine nutrition products were launched on the international market. In the United States, $64 \%$ of pet owners are interested in premium or natural snacks. In this scenario, in the last five years, pet treats ranked first when compared to feline and canine meals, with growth of $11 \%$ when compared to meals that presented $8 \%$ growth (Mintel, 2018).

Among the different sectors of the pet industry, the market related to the consumption habits of the animal owners stands out, including canine vegan products, which demonstrates a close relationship between animals and owners. These products can be produced using functional ingredients as a marketing strategy, or to complete macro and micronutrient proportions, thus providing a balanced vegan diet (Knight \& Leitsberger, 2016).

In addition to the use of natural ingredients, the search for a clean label without the use of additives has led the market to avoid the use of artificial dyes and synthetic antioxidants, and fruits and vegetables have been used for this purpose (Oliveira et al., 2020; Sousa et al., 2020). This study used blackberry, a regional fruit with significant availability in Brazil, which stands out for its phenolic content, similar to other berries, besides its antioxidant activity and typical color, which can generate higher value-added products (Clerici \& Carvalho-Silva, 2011). The intake of antioxidants has been related to the improvement of cognitive function in elderly dogs (Hall et al., 2006) and reduction of oxidative damage after exercise in dog athletes (Dunlap et al., 2006).

Hydrolyzed soy protein has been used in animal formulations since it contains proteins with higher availability and 
better digestibility, increasing intestinal absorption. In a review of the dietary use of hydrolyzed proteins in dog diets, Olivry \& Bizikova (2010) reported that this type of diet can reduce and even eliminate the allergic response in dogs due to the reduced protein size after hydrolysis, which may be a positive factor for dog nutrition.

Prebiotic fibers are important foods for the regulation of the intestinal microbiota (Moro et al., 2018; Nabeshima et al., 2020). Prebiotic fibers have already been used in animal food since they increase the Bifidobacteria population, leading to a reduction of bacteria that produce compounds related to colon disease and foul-smelling stools (Hussein et al., 1999). In addition, the consumption of prebiotic fibers also increases the absorption of $\mathrm{Ca} / \mathrm{Mg}$, regulates intestinal function, increases bone mineral content, reduces triglyceridemia and cholesterol, and improves immunity (Di Cerbo et al., 2017; Roberfroid, 2005).

The objective of the present study was to produce vegan canine biscuits containing inulin, hydrolyzed soy protein, and blackberry flour to obtain snacks with prebiotic and antioxidant activities.

\section{Methodology}

\subsection{Raw material}

Wheat flour, hydrolyzed soy protein concentrate (Imunoprotein ${ }^{\circledR}$ ), and blackberry used in the biscuit formulations were donated by the industry. The other food ingredients were purchased in the local market. All other chemicals were of the highest analytical grade. Bifidobacterium bifidum G90® (BioGrowing Co. Ltd., Shanghai, China) as a lyophilized powder (1011 UFC/g) was stored under $7^{\circ} \mathrm{C}$ until use.

\subsection{Physicochemical and rheological characterization of wheat flour}

The proximate composition of wheat flour was determined according to the Commission Regulation (EC) 152/2009 (FEDIAF, 2019) using the methodologies of AOAC (2006) and AACCI (2010). Moisture, protein, ash, and ether extract contents were determined according to AOAC (2006) using the methods 925.09, 960.52 (conversion factor 5.7), 923.39, and 945.16, respectively. The total fiber was measured with the Megazyme ${ }^{\circledR}$ Total Dietary Fiber Assay kit (K-TDFR 06/14) according to manufacturer's instructions, as described in the methodologies 32-05.01 (AACCI, 2010) and 985.29 (AOAC, 2006). Other carbohydrates were calculated by difference according to the following formula: 100 - (moisture + protein + ash + ether extract + total dietary fiber). The Farinograph (54-21.02) and Extensograph (54-10.01) analyses were carried out to determine the force and the water absorption of wheat flour (AACCI, 2010).

\subsection{Preparation of vegan canine biscuits}

The formulations met the recommendations required by the European Pet Food Industry (FEDIAF, 2019) for complementary pet food, category A. The vegan biscuits formulations are shown in Table 1, in which CB1 corresponds to the control formulation, while the formulations CB2, CB3, and CB4 were made with different concentrations of inulin. The concentration of blackberry flour (BBF) was set at $50 \mathrm{~g} / \mathrm{kg}$. In addition to these functional ingredients, $35 \mathrm{~g} / \mathrm{kg}$ of hydrolyzed soy protein concentrate (HSP, Imunoprotein ${ }^{\circledR}$ ) was used in the formulations CB2, CB3, and CB4. The manufacture of the biscuits was carried out according to the following steps: manual mixing of the ingredients, rest (5 min.), molding and cutting, baking in an electric oven (Pratica, Pouso Alegre, Brazil) at $180^{\circ} \mathrm{C}$ for $7 \mathrm{~min}$., cooling at room temperature (for $120 \mathrm{~min}$.), and packaging in a multilayer laminated package ( $85 \mu \mathrm{m}$ thick). 
Table 1. Ingredients of the canine vegan biscuits with variation in the contents of wheat flour (WF), inulin, hydrolyzed soy protein (HSP), and blackberry flour (BBF).

\begin{tabular}{ccccc}
\hline Ingredients (g/kg) & $\begin{array}{c}\text { CB1 } \\
\text { (control) }\end{array}$ & CB2 & CB3 & CB4 \\
\hline Wheat flour & 735 & 620 & 590 & 560 \\
Inulin & 0 & 30 & 60 & 90 \\
Hydrolyzed soy protein (HSP) & 0 & 35 & 35 & 35 \\
Blackberry flour (BBF) & 0 & 50 & 50 & 50 \\
Soy lecithin & 5 & 5 & 5 & 5 \\
Palm fat & 80 & 80 & 80 & 80 \\
Water & 180 & 180 & 180 & 180 \\
\hline
\end{tabular}

Source: Authors.

\subsection{Technological quality of biscuits}

For the technological evaluation, ten units of biscuits were sampled for each analysis. The determinations were performed according to AACCI (2010): The diameter and thickness of the biscuits were measured with the aid of a Caliper. The diameter $(\mathrm{mm})$ was measured with the aid of paper, where the biscuit diameter was marked before and after baking, and the difference was considered as horizontal growth (\%). The vertical growth was determined by the difference (\%) between the average thickness of the biscuits before and after baking. The mass loss was calculated by the difference (\%) between the average mass of the biscuits before and after the baking. The specific volume was established by the seed displacement method, using a $50 \mathrm{~cm} 3$ test tube, according to the methodology 10-05.01 (AACCI, 2010).

\subsubsection{Color and instrumental texture}

Color measurements were performed using the Mini ScanXE HunterLab colorimeter (Reston MINOLTA, Virginia, USA) by determining the parameters $\mathrm{L}^{*}, \mathrm{a}^{*}$, and $\mathrm{b} *$ using the CIELab system, with illuminant D65 and $10^{\circ}$ angle. $\mathrm{L}^{*}$ values vary from zero (black) to 100 (white), and the chromaticity coordinates $a^{*}$ and $b^{*}$ vary from -a (green) to $+a$ (red), and -b (blue) to $+b$ (yellow), respectively. The hardness of the biscuits was determined in Newton $(\mathrm{N})$ using a TA-XT2i texture analyzer (Stable Micro Systems, England), using three-point bending probe, and pre-test speed $2 \mathrm{~mm} / \mathrm{s}$, test speed $3 \mathrm{~mm} / \mathrm{s}$, and distance $5 \mathrm{~mm}$.

\subsection{Sensory evaluation}

The paired t-test was used to evaluate the acceptability and palatability of the samples. Two samples were presented to the dogs simultaneously, to be consumed in a defined period of time. Thus, the preference of the dog based on the amount of the biscuit ingested was established. For each pair of samples, a second test was required, replacing the sample position, to pre vent the dog position preference. The second test allowed measuring the repeatability of the evaluation (Rofe \& Anderson, 1970). In addition, according to the methodology of the Center for Nutritional Development of the company PremieR Pet ${ }^{\circledR}$ (Dourado, Brazil), the sensory evaluation was focused on the following aspects:

- The interest of the dog in consuming the sample: scores varied from "Yes", "No" to "Partially".

-Ingestion of the sample: this parameter analyzed the amount of sample ingested, ranging from 1 to 3, where $1=$ biscuits were not ingested, 2 = biscuits were ingested after a certain time, and $3=$ biscuits were ingested.

- Interest of the dog in consuming the sample: the scores varied from 1 to 5 , where $1=$ the dog does not look at the biscuit and does not ingested it, 2 = the dog does not rejoice when seeing the biscuit and takes a few minutes to eat it, $3=$ the dog was 
indifferent, $4=$ the dog liked the biscuit and $5=$ the dog loved the biscuit.

- The first choice of the dog: this parameter analyzed the first choice of the dog in the two days of tests for the same samples.

The acceptability and palatability of the biscuits were investigated at the Nutrition Development Center of the company PremieR Pet ${ }^{\circledR}$, in Dourado - Brazil, using 17 adult dogs, male or female. The animals did not have their routine altered, were individually loose or in affinity groups, in their own kennel, exercise areas and/or parks. The biscuits were offered in the afternoon, after the second meal of the day, in a paired t-test (biscuit A versus biscuit B). The experimental period lasted six days, divided into three groups of samples ( $\mathrm{CB} 1 \mathrm{xCB} 3, \mathrm{CB} 1 \mathrm{xCB} 4, \mathrm{CB} 3 \mathrm{xCB} 4)$. On the first day, biscuit A was served in the right hand and biscuit $\mathrm{B}$ in the left hand, and on the second day, biscuit $\mathrm{B}$ in the right hand and biscuit $\mathrm{A}$ in the left hand. The analysis was classified as G1 (minimally invasive technique), according to Brazilian legislation for the control of animal experiments (Brazil, 2008). The documents of the tacit approval were endorsed by the Ethical Committee on the Use of Animals - CEUA of the Premier-Pet ${ }^{\circledR}$, under the protocol number Bioethics 057-16.

\subsection{Pasting properties of the vegan canine biscuits}

The starch pasting properties of the biscuits were determined in the Rapid Visco Analyzer (RVA) using the Standard 1 profile, according to methodology 76-21.01 (AACCI, 2010).

\subsection{Physicochemical and functional evaluation of vegan canine biscuits}

\subsubsection{Proximate composition}

The proximate composition of the formulations submitted to the sensory analysis was performed according to Section 2.2, except for the total dietary fiber content, which was calculated from the ingredients values of total dietary fiber provided by the suppliers, and protein content nitrogen conversion factor was 6.25 .

\subsubsection{In vitro prebiotic activity}

The in vitro prebiotic activity of canine vegan biscuits was determined according to the methodology of Li et al. (2008) adapted by Moro et al. (2018). The MRS broth supplemented with $0.5 \mathrm{~g} / \mathrm{L}$ L-cysteine hydrochloride; $2 \mathrm{~g} / \mathrm{L}$ sodium thioglycolate; and $0.1 \mathrm{~g} / \mathrm{L}$ sodium chloride was dispensed into tubes containing the biscuit formulations (3\% w/v) in the final ratio of $9.9 \mathrm{~mL}$ (four replicates). The tubes were inoculated with Bifidobacterium bifidum G90 (BioGrowing Co. Ltd., Shanghai, China), $0.1 \mathrm{ml}$, with a population of 106 cells / $\mathrm{mL}$. The microorganisms were spiked by activating the lyophilized bacteria in supplemented MRS broth and incubating under anaerobic conditions at $37{ }^{\circ} \mathrm{C} / 18 \mathrm{~h}$. The test tubes, the positive control (inoculum in supplemented MRS) and the negative control (supplemented MRS inoculum free) were incubated at $37{ }^{\circ} \mathrm{C}$ in anaerobic jars for $24 \mathrm{~h}$. After incubation, the tubes were centrifuged (3000x g) for $10 \mathrm{~min}$., and the supernatant was discarded. Then, $15 \mathrm{~mL}$ of PBS (0.1 M phosphate buffer $\mathrm{pH} 7.4,0.9 \%$ saline) was added to the tubes and agitated for 2 min. Turbidity readings were performed at $600 \mathrm{~nm}$, using a UV/Vis DU70 spectrophotometer (Beckman Instruments, Inc., Fullerton, USA).

\subsubsection{Total phenolic compounds (TPC)}

The total phenolic compounds (TPC) were determined by the Folin Ciocalteau method using a standard curve with different concentrations of gallic acid, and the results were expressed as mg equivalents of gallic acid per kg sample (mg GAE/kg) (Roesler et al., 2007). 


\subsubsection{Antioxidant capacity (AC)}

The antioxidant capacity was determined by the TEAC (Trolox equivalent antioxidant capacity) method, according to the methodology described by Re et al. (1999) using the radical ABTS ${ }^{+}$. Trolox was used as the standard for the preparation of the calibration curve, and the results were expressed as $\mu \mathrm{mol}$ Trolox equivalents $/ \mathrm{kg}$ sample.

\subsection{Statistical Analysis}

Data were submitted to analysis of variance and Scott-Knott's test by SISVAR® software, at a significance level of 5\% ( $p<0.05$ ) for comparison of means.

\section{Results}

\subsection{Physicochemical characterization of wheat flour}

Wheat flour (WF) presented $118.2 \pm 0.43 \mathrm{~g} / \mathrm{kg}$ moisture, $13.9 \pm 1.23 \mathrm{~g} / \mathrm{kg}$ ash; $10.5 \pm 0.23 \mathrm{~g} / \mathrm{kg}$ lipids; $97.6 \pm 0.12 \mathrm{~g} / \mathrm{kg}$ proteins on wet basis, and $733.1 \mathrm{~g} / \mathrm{kg}$ carbohydrates; and $23.5 \pm 0.29 \mathrm{~g} / \mathrm{kg}$ total dietary fiber. Table 2 shows the results of the rheological characterization of wheat flour.

Table 2. Farinograph and extensograph parameters of wheat flour ${ }^{1}$.

\begin{tabular}{|c|c|c|c|}
\hline \multirow{5}{*}{ Farinograph } & \multicolumn{2}{|c|}{ Determination } & \multirow{2}{*}{$\begin{array}{c}\text { Results } \\
58.20\end{array}$} \\
\hline & & tion $(\%)$ & \\
\hline & \multicolumn{2}{|c|}{ Dough development time (min.) } & $15.33 \pm 0.25$ \\
\hline & \multicolumn{2}{|c|}{ Stability (min.) } & $23.07 \pm 0.76$ \\
\hline & \multicolumn{2}{|c|}{ Mixing tolerance index (FU) } & $24.67 \pm 2.89$ \\
\hline \multirow{15}{*}{ Extensograph } & \multirow{5}{*}{45 min. } & $\mathrm{R}$ (UE) & $525.0 \pm 3.5^{\mathrm{c}}$ \\
\hline & & $\mathrm{R}(\mathrm{RM})$ & $705.0 \pm 5.0^{\mathrm{c}}$ \\
\hline & & $\mathrm{E}(\mathrm{mm})$ & $125.0 \pm 7.0^{\mathrm{a}}$ \\
\hline & & $\mathrm{A}\left(\mathrm{cm}^{2}\right)$ & $112.0 \pm 6.0^{\text {n.s. }}$ \\
\hline & & $\mathrm{D}(\mathrm{UE} / \mathrm{mm})$ & $4.2 \pm 0.5^{\mathrm{c}}$ \\
\hline & \multirow{5}{*}{$90 \mathrm{~min}}$. & R (UE) & $874.0 \pm 2.4^{\mathrm{b}}$ \\
\hline & & $\mathrm{R}(\mathrm{RM})$ & $1003.0 \pm 4.0^{\mathrm{b}}$ \\
\hline & & $\mathrm{E}(\mathrm{mm})$ & $105.0 \pm 5.0^{\mathrm{b}}$ \\
\hline & & $\mathrm{A}\left(\mathrm{cm}^{2}\right)$ & $129.0 \pm 9.0^{\text {n.s. }}$ \\
\hline & & $\mathrm{D}(\mathrm{UE} / \mathrm{mm})$ & $8.3 \pm 0.5^{\mathrm{b}}$ \\
\hline & \multirow{5}{*}{$135 \mathrm{~min}}$. & R (UE) & $998.0 \pm 5.3^{\mathrm{a}}$ \\
\hline & & $\mathrm{R}(\mathrm{RM})$ & $1056.0 \pm 3.0^{\mathrm{a}}$ \\
\hline & & $\mathrm{E}(\mathrm{mm})$ & $93.0 \pm 2.0^{c}$ \\
\hline & & $\mathrm{A}\left(\mathrm{cm}^{2}\right)$ & $117.0 \pm 7.0^{\text {n.s. }}$ \\
\hline & & $\mathrm{D}(\mathrm{UE} / \mathrm{mm})$ & $10.7 \pm 0.4^{\mathrm{a}}$ \\
\hline
\end{tabular}

${ }^{1}$ Values expressed as mean \pm standard deviation. Different letters in the extensograph intervals differ by the Scott-Knott test (p-value $<0.05$ ); ns: not significant. FU: Farinograph units. R: Resistance; MR: Maximum resistance; E: Extensibility; A: Energy; D: Proportional number (Resistance/Extensibility); EU: Extensograph units. Source: Authors.

The farinograph and extensograph analyses (Table 2) characterized wheat flour (WF) as strong, once it exhibited water absorption capacity higher than 58\%, dough development time greater than 10 minutes, dough stability higher than 15 minutes, and extension parameters characteristic of strong flour (Cauvain, 2015). As strong flours are not suitable for biscuits, the use of diluents becomes necessary, thus hydrolyzed soy protein, inulin, and blackberry were used, which are different from starch commonly used due to its lower cost. However, starch increases the content of digestible carbohydrates in the product, therefore it is not recommended for dogs. 


\subsection{Evaluation of the technological quality of vegan canine biscuit formulations}

The images and the results of the technological quality of vegan canine biscuits are shown in Figure 1 and Table 3, respectively. The control biscuit (CB1) presented light yellow color, while the formulations CB2, CB3, and CB4 exhibited a darker color after the baking step, which was expected for this product, besides the color corresponding to the anthocyanins contents of BBF, with no significant differences between them. However, they were different from the control formulation, with a darker and reddish tone, which is demonstrated by the lower $\mathrm{L}^{*}$ values and higher $\mathrm{a}^{*}$ values, corresponding to the red color. These results are very interesting because, although dogs do not see the red color (Byosiere et al., 2018), it is attractive to the owners who buy the products, and the natural coloring appeal adds value to the product.

The addition of the functional ingredients HSP, BBF, and inulin significantly reduced the hardness of the biscuits CB2, CB3, and CB4 when compared to the control biscuit (CB1). Other technological parameters such as specific volume and mass loss were not significantly affected. The horizontal growth of CB2 and the vertical growth of CB3 were higher than the other samples, with no effect of the inulin addition. The use of ingredients to replace wheat flour can lead to a reduction of the gluten content, which increases the extensibility and the spreadability of the products, thus leading to greater horizontal growth when compared to biscuits made with strong wheat flour (Manley, 2000).

Table 3. Technological, physicochemical, functional, pasting, and sensory characteristics of canine vegan biscuits: CB1 (control, without inulin), CB2 (30 g/kg of inulin), CB3 (60 g/ $\mathrm{kg}$ of inulin) and CB4 (90g/kg of inulin) ${ }^{1}$.

\begin{tabular}{|c|c|c|c|c|}
\hline Canine biscuits (CB) & CB1 (control) & CB2 & CB3 & CB4 \\
\hline \multicolumn{5}{|c|}{ Technological properties } \\
\hline Color: & & & & \\
\hline $\mathrm{L}^{*}$ & $62.70 \pm 0.74^{\mathrm{a}}$ & $33.92 \pm 1.16^{\mathrm{b}}$ & $34.01 \pm 0.21^{\mathrm{b}}$ & $33.52 \pm 0.33^{\mathrm{b}}$ \\
\hline$a^{*}$ & $7.41 \pm 0.51^{\mathrm{b}}$ & $12.21 \pm 0.17^{\mathrm{a}}$ & $12.55 \pm 0.22^{\mathrm{a}}$ & $12.85 \pm 0.09^{\mathrm{a}}$ \\
\hline$b^{*}$ & $28.85 \pm 1.12^{\mathrm{a}}$ & $16.37 \pm 0.22^{\mathrm{b}}$ & $17.24 \pm 0.74^{\mathrm{b}}$ & $14.97 \pm 0.85^{\mathrm{b}}$ \\
\hline$\Delta \mathrm{E}$ & & $31.74 \pm 1.01$ & $31.39 \pm 0.12$ & $32.78 \pm 0.32$ \\
\hline Hardness $(\mathrm{N})$ & $29.76 \pm 2.19^{\mathrm{a}}$ & $23.57 \pm 2.27^{\mathrm{b}}$ & $19.65 \pm 1.88^{c}$ & $21.47 \pm 1.80^{\mathrm{c}}$ \\
\hline $\begin{array}{l}\text { Specific volume } \\
\left(\mathrm{cm}^{3} / \mathrm{g}\right)\end{array}$ & $3.28 \pm 1.09^{\text {n.s. }}$ & $2.06 \pm 0.88^{\text {n.s. }}$ & $2.72 \pm 0.91^{\text {n.s. }}$ & $2.41 \pm 1.03^{\text {n.s. }}$ \\
\hline Mass loss (\%) & $36.99 \pm 4.49^{\text {n.s. }}$ & $35.41 \pm 3.50^{\text {n.s. }}$ & $33.26 \pm 5.92^{\text {n.s. }}$ & $36.05 \pm 3.74^{\text {n.s. }}$ \\
\hline Vertical growth $(\mathrm{cm})^{2}$ & $0.17 \pm 0.03^{\mathrm{b}}$ & $0.19 \pm 0.03^{\mathrm{b}}$ & $0.24 \pm 0.05^{\mathrm{a}}$ & $0.16 \pm 0.04^{\mathrm{b}}$ \\
\hline $\begin{array}{l}\text { Horizontal growth } \\
(\mathrm{mm})^{2}\end{array}$ & $0.24 \pm 0.14^{\mathrm{b}}$ & $0.34 \pm 0.04^{\mathrm{a}}$ & $0.20 \pm 0.11^{\mathrm{b}}$ & $0.24 \pm 0.09^{\mathrm{b}}$ \\
\hline \multicolumn{5}{|c|}{ Physicochemical and functional properties } \\
\hline Moisture $(\mathrm{g} / \mathrm{kg})$ & $44.91 \pm 1.44^{\circ}$ & n.d. & $58.98 \pm 1.21^{\mathrm{b}}$ & $61.52 \pm 0.82^{\mathrm{a}}$ \\
\hline Proteins $(\mathrm{g} / \mathrm{kg})$ & $98.65 \pm 1.14^{\mathrm{b}}$ & n.d. & $115.21 \pm 1.32^{\mathrm{a}}$ & $114.29 \pm 1.15^{\mathrm{a}}$ \\
\hline Ash $(\mathrm{g} / \mathrm{kg})$ & $6.32 \pm 0.09^{c}$ & n.d. & $8.55 \pm 0.20^{\mathrm{b}}$ & $8.97 \pm 0.11^{\mathrm{a}}$ \\
\hline Lipids $(\mathrm{g} / \mathrm{kg})$ & $111.05 \pm 0.85^{\mathrm{c}}$ & n.d. & $121.04 \pm 0.50^{\mathrm{b}}$ & $123.11 \pm 0.30^{\mathrm{a}}$ \\
\hline $\begin{array}{l}\text { Total dietary fiber } \\
(\mathrm{g} / \mathrm{kg})^{2}\end{array}$ & 23.11 & n.d. & 119.07 & 148.37 \\
\hline Carbohydrates $(\mathrm{g} / \mathrm{kg})^{3}$ & 715.96 & n.d. & 577.15 & 543.74 \\
\hline Prebiotic Activity & $0.40 \pm 0.03^{b}$ & n.d. & $0.61 \pm 0.05^{\mathrm{a}}$ & $0.59 \pm 0.03^{\mathrm{a}}$ \\
\hline $\begin{array}{l}\text { Phenolic compounds } \\
\text { (mg gallic acid } \\
\text { equivalent } / \mathrm{kg} \text { ) }\end{array}$ & $13.85 \pm 1.12^{\mathrm{b}}$ & n.d. & $18.03 \pm 0.35^{\mathrm{a}}$ & $17.48 \pm 0.05^{\mathrm{a}}$ \\
\hline $\begin{array}{c}\text { Antioxidant capacity } \\
(\mu \text { mol Trolox } \\
\text { equivalent } / \mathrm{kg})\end{array}$ & $377.63 \pm 35.33^{c}$ & n.d. & $890.23 \pm 42.43^{\mathrm{a}}$ & $556.48 \pm 56.44^{\mathrm{b}}$ \\
\hline \multicolumn{5}{|c|}{ Pasting properties $^{4}$} \\
\hline $\begin{array}{l}\text { Maximum viscosity } \\
\text { (cP) }\end{array}$ & $265.0 \pm 4.2^{\mathrm{a}}$ & n.d. & $125.5 \pm 6.4^{\mathrm{b}}$ & $89.0 \pm 0.1^{\mathrm{c}}$ \\
\hline $\begin{array}{l}\text { Minimum viscosity } \\
\text { (cP) }\end{array}$ & $227.5 \pm 3.5^{\mathrm{a}}$ & n.d. & $117.5 \pm 6.4^{\mathrm{b}}$ & $82.5 \pm 0.7^{\mathrm{c}}$ \\
\hline Breakdown (cP) & $37.5 \pm 0.7^{\mathrm{a}}$ & n.d. & $8.0 \pm 0.1^{\mathrm{b}}$ & $6.5 \pm 0.7^{\mathrm{c}}$ \\
\hline
\end{tabular}




\begin{tabular}{|c|c|c|c|c|}
\hline Setback (cP) & $370.5 \pm 0.7^{\mathrm{a}}$ & n.d. & $183.5 \pm 4.9^{\mathrm{b}}$ & $120.5 \pm 2.1^{\mathrm{c}}$ \\
\hline Final viscosity $(\mathrm{cP})$ & $598.0 \pm 2.8^{\mathrm{a}}$ & n.d. & $301.0 \pm 11.3^{\mathrm{b}}$ & $203.0 \pm 1.4^{\mathrm{c}}$ \\
\hline $\begin{array}{l}\text { Pasting temperature } \\
\left({ }^{\circ} \mathrm{C}\right)\end{array}$ & $92.0 \pm 0.1^{\text {n.s. }}$ & n.d. & $91.1 \pm 0.1^{\text {n.s. }}$ & $91.6 \pm 0.7^{\text {n.s. }}$ \\
\hline \multicolumn{5}{|c|}{ Sensory evaluation } \\
\hline Dogs' first choice $(\%)$ & 55.4 & n.d. & 50.9 & 54.2 \\
\hline Biscuits ingestion (\%) & 37.5 & n.d. & 29.8 & 40.7 \\
\hline Dogs enthusiasm $^{5}$ & $3.77 \pm 0.67^{\text {n.s. }}$ & n.d. & $3.86 \pm 0.89^{\text {n.s. }}$ & $3.78 \pm 0.78^{\text {n.s. }}$ \\
\hline
\end{tabular}

Values expressed as mean \pm standard deviation. Different letters in the line differ by the Scott-Knott test (p-value<0.05); n.s.: not significant. n.d.: not determined. ${ }^{2}$ Calculated according to the suppliers' information for total dietary fiber of ingredients. ${ }^{3} \mathrm{Calculated}$ by difference. ${ }^{4} \mathrm{cP}$ : centipoises. ${ }^{5}$ Trainers's perception: $4=$ The dog enjoyed the sample; $3=$ The dog was indifferent. Source: Authors.

Figure 1. Scanned images of the canine vegan biscuits CB1 (control, without inulin), CB2 (30 g/kg of inulin), CB3 (60 g/kg of inulin), and CB4 (90g/kg of inulin).

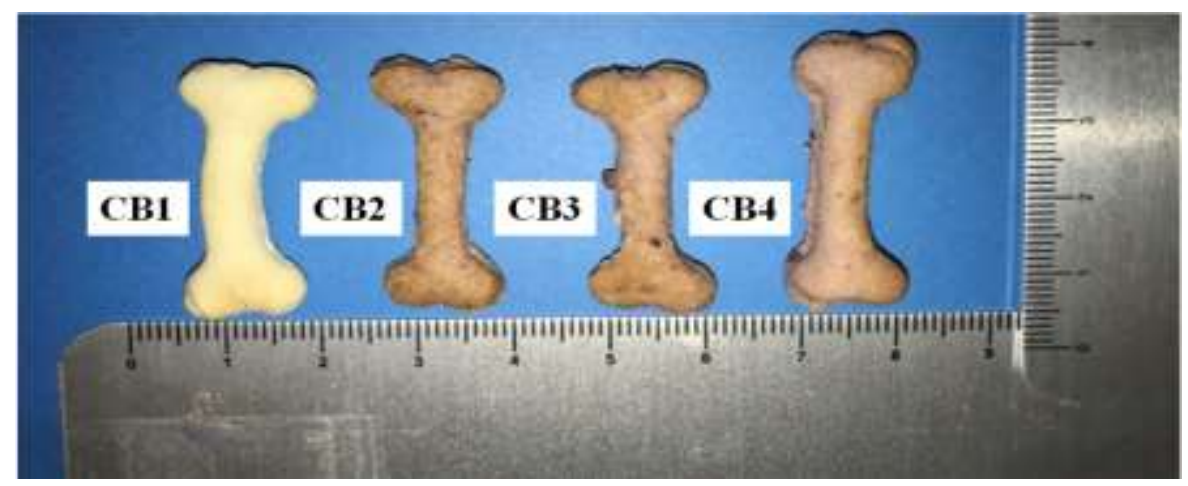

Source: Authors.

\subsection{Sensory evaluation}

The biscuits were selected from the results of Table 3 , which shows that the addition of inulin at different concentrations caused minimal changes in their technological properties. Therefore, the samples CB3 and CB4 with the highest inulin content were selected for the sensory evaluation, and CB1 was used as a control. For the sensory tests, 17 dogs with mean age of $2.59 \pm$ 0.02 years and weight of $11.74 \pm 0.53 \mathrm{~kg}$ were selected. The breeds that participated in the tests were: Border Collie $(\mathrm{n}=1)$, French Bulldog ( $n=4)$, Cocker ( $n=2)$, Pug $(n=2)$, Irish Setter $(n=2)$, West Highland White Terrier $(n=2)$, Whippet $(n=2)$ and Yorkshire ( $\mathrm{n}=2)$. Of these, 10 animals were male $(59 \%)$ and seven were female $(41 \%)$. The dogs' interest in the samples was $84.3 \%$ throughout the six days of testing. Table 3 presents the frequency (\%) of the first choice of biscuits and the intake of the whole sample. The dogs' enthusiasm when ingesting the samples was measured by the trainer's perception. Figure 2 shows the score distribution for each sample. 
Figure 2. Frequency (\%) of the dogs' enthusiasm when ingesting the samples: CB1 (control, without inulin), CB3 (60 g/kg of inulin) and CB4 (90g/kg of inulin).

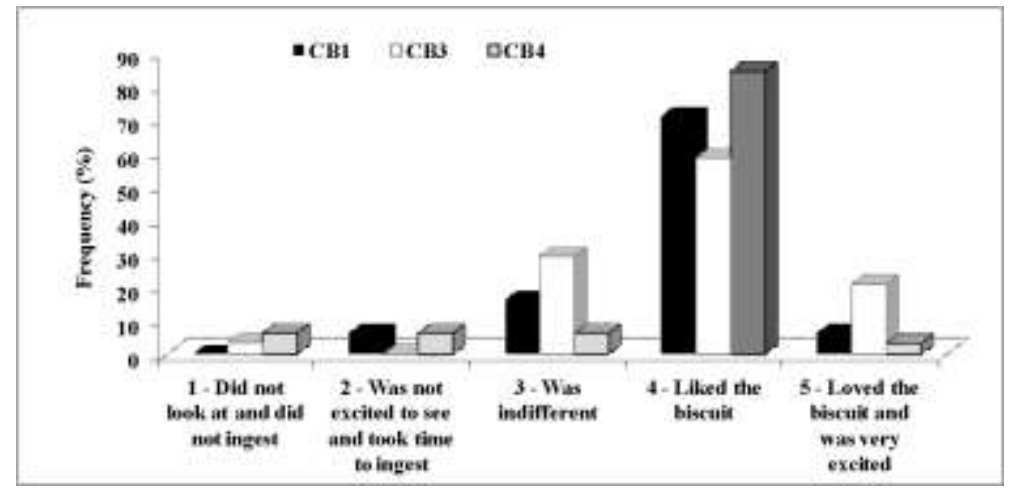

Source: Authors.

No significant difference was observed for the dogs' enthusiasm when ingesting the samples, as shown in Table 3. Figure 2 shows the prevalence of score 4 for all formulations, indicating that the dogs accepted the vegan snack, which is a positive result for the palatability of the ingredients used. However, it was not possible to evaluate if a sample was preferred over the others.

\subsection{Physicochemical and functional characterization of the biscuits}

Table 3 shows the results of the physicochemical and functional characterization of vegan biscuits. Regarding the moisture content, a significant difference was observed between the samples CB1 (control), CB3, and CB4, probably due to the addition of inulin to CB3 and CB4, which presented higher moisture with the increase in inulin concentration. The results of ash and lipids showed a significant difference by the Scott-Knott test $(\mathrm{p}<0.05)$ with higher values for the sample CB4 $(90 \mathrm{~g} / \mathrm{kg}$ inulin). The addition of hydrolyzed soy protein to CB3 and CB4 biscuits significantly increased the protein content by $15 \%$ when compared to $\mathrm{CB} 1$. The formulations $\mathrm{CB} 3$ and $\mathrm{CB} 4$ showed significantly higher in vitro prebiotic activity when compared to the control (CB1), without the addition of inulin. Inulin, which is recognized as a bifidogenic ingredient (Roberfroid, 2007), exhibited no changes in functionality after the processing stages such as mixing, molding and baking, as well as its interaction with the other ingredients used (fat, wheat flour, and soy lecithin), indicating that these snacks can be used to deliver prebiotics to consumers of this product. The TPC and the antioxidant capacity were higher in the formulations CB3 and CB4 when compared to the control, probably due to the addition of blackberry flour, which has functional compounds comparable to other berries.

\subsection{Pasting properties of the vegan biscuits}

The results of the pasting properties of the samples (CB1, CB3, and CB4) are shown in Table 3, and the graphical representation is shown in Figure 3. The results of refined wheat flour used in the biscuits formulation were displayed at Figure 3 with native wheat flour and the samples CB1, CB3, and CB4. 
Figure 3. Pasting profile by the rapid visco analyzer (RVA) of raw wheat flour and canine biscuits: CB1 (control, without inulin), CB3 (60 g/kg of inulin), and CB4 (90g/kg of inulin).

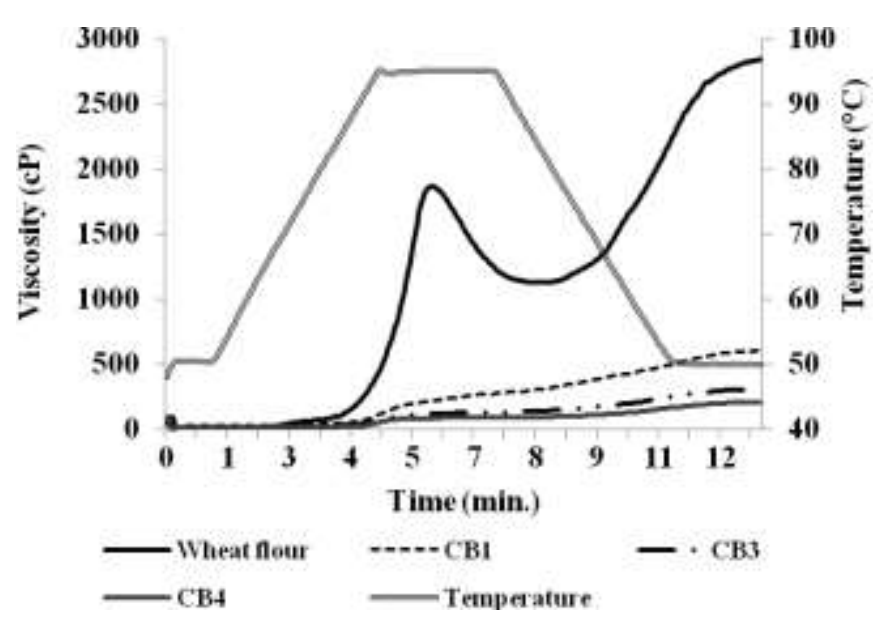

Source: Authors.

The biscuits had lower viscosity values when compared to the native WF, with a viscosity curve characteristic of this raw material. The lower viscosity of the biscuits may be due to the effect of baking on the starch granules after the addition of water $(25 \%)$ and fat $(11 \%)$ to the dough. A great reduction was observed in the samples with the addition of inulin, BBF, and HSP, probably due to the proportional reduction of WF in the formulations.

\section{Results}

The physicochemical characterization of wheat flour for the moisture, lipids, protein, and carbohydrate contents are in accordance with those found by the United States Department of Agriculture (USDA, 2015) and are in compliance with the Brazilian legislation (Brazil, 2005). The wheat flour used in this study was characterized as strong flour (Table 2), which allowed its substitution by inulin, blackberry flour, and hydrolyzed soy protein, without damaging the processing and technological characteristics of the biscuits, which showed the absence of cracks in all samples. The thermoplastic extrusion is used in the pet product industry for the production of most dry products, due to the effects of baking, mixing and molding steps, which improves palatability and digestibility of the products (Cheftel, 1986). The ingredients used in biscuits processing also led to the production of samples with easy shaping and homogeneous appearance, with no loss in cutting and baking steps. Ayyappan et al. (2016) elaborated cookies with commercial xylooligosaccharides and reported that the substitution of sugar with fiber led to an increase in hardness. In biscuits manufacture, weak flour generates products with better technological and sensory quality, and parameters such as hardness can increase with the addition of other ingredients, mainly fibers. Opposite behavior was observed in the present study, since the formulation was made with strong flour (Table 2), which was substituted by other ingredients (at 11.5, 14.5, and $17.5 \%$ ), thus lower hardness was expected due to the dilution effect in the wheat flour.

From the results of the technological characterization, the biscuits with the highest inulin contents (CB3 and CB4) were selected for the acceptability and palatability tests, together with the control sample (CB1). All biscuits were accepted by the dogs, with no preference among the three samples. The addition of functional ingredients is a trend in the pet market, and products with health claims have been developed (Knight \& Leitsberger, 2016). However, studies on the application of functional ingredients for dogs are still scarce. Strickling et al. (2000) evaluated the palatability of canine meal containing $5 \mathrm{~g} / \mathrm{kg}$ of commercial oligosaccharide, and also observed no rejection or preference for the samples. Chen et al. (2016) developed canine meal rich in antioxidants containing up to $1 \%$ tea extract. The dogs preferred the samples with up to $0.5 \%$, demonstrating they 
may perceive the changes in flavor, with a consequent change in their consumption pattern. Due to the acceptance of samples $\mathrm{CB} 1, \mathrm{CB} 3$, and CB4, they were subjected to physicochemical characterization and determination of the functional properties. The digestibility of ready-to-eat products is a concern in animal feed. In starch-based products, it is desirable that starch is partially or fully gelatinized to prevent digestive problems in dogs, once they possess pancreatic amylase rather than salivary amylase, thus the starch digestion is slower (Axelsson et al., 2013).

The results of RVA (Table 4 and Figure 3) indicate that the biscuits presented lower viscosity and smoother curves (Figure 3) due to the addition of other ingredients and heating during the baking step. In a traditional biscuit formulation, sugars such as sucrose and glucose syrup act to reduce the degree of gelatinization of starch granules (Chevallier et al., 2000). However, the absence of these ingredients may have contributed to increase the degree of gelatinization, and consequently the availability of carbohydrates.

The moisture contents of the vegan canine biscuits were within the range indicated by FEDIAF, which requires up to $140 \mathrm{~g} / \mathrm{kg}$ moisture for dry pet products. In relation to the protein, ash, lipids, and fiber contents, all samples follow the FEDIAF recommendations for complementary feeding of category A - Snacks (FEDIAF, 2019).

Diet affects the composition of the intestinal microbiota of humans and animals. Prebiotic carbohydrates are intended to provide an energy source for the beneficial species that reside in the intestine. The in vitro evaluation indicated that inulin added to the cookies favored the development of probiotics, which may also occur in the intestine of the animals (Biagi et al., 2010; Di Cerbo et al., 2017; Kozłowska et al., 2016).

Biagi et al. (2010) and Propst et al. (2003) reported the beneficial effect of oligosaccharides as inulin for the digestibility of nutrients in the diet of dogs. Thus, the use of inulin in canine vegan biscuits may bring health benefits for the dogs. Wang \& Lin (2000) found about $2.26 \mathrm{~g} / \mathrm{kg}$ phenolic compounds in blackberry flour, which are responsible for the antioxidant activity of the fruit. In this study, the addition of blackberry flour at $50 \mathrm{~g} / \mathrm{kg}$ altered the color of the samples (light pink) when compared to the control biscuit, and significantly increased the TPC content and the antioxidant capacity. Chen et al. (2016) investigated the addition of an antioxidant-rich tea (Camellia sinensis) to a canine meal and reported a greater sensory acceptance at extract concentrations of 0.25 and $0.50 \%$. The authors concluded that this ingredient may have caused sensory changes in the meal, which were perceived by dogs. The addition of blackberry flour can be considered as an alternative for the enrichment of baking products, conferring color and flavor, besides contributing to the ingestion of phenolic compounds (Pereira et al., 2019). Therefore, the addition of this flour may be an effective alternative to increase the antioxidant capacity in canine snacks.

\section{Conclusion}

The addition of functional ingredients in vegan canine biscuits led to some changes in its technological properties, which did not affect the quality of the final product. Although dogs had no preference for a particular sample, they accepted the flavor of the ingredients used in the formulations CB1, CB3, and CB4. The results of the functional properties showed that biscuits CB3 and CB4 presented positive effects when compared to the control (CB1) for the prebiotic activity and the antioxidant capacity. This study demonstrated the possibility of using the ingredients inulin and blackberry flour to enhance healthiness of vegan canine biscuits and to deliver prebiotics and antioxidants in dogs' food products.

\section{Acknowledgments}

The authors thank FAPESP (2016 10936-1) and CNPq for the scientific initiation grants, and CAPES for the doctoral scholarship (financial code 001). They also thank FAPESP (project 2015/196374). Thanks go also to the PremieR® Pet for the 
aid during the sensory evaluation and Anaconda Industrial mill (São Paulo, Brazil) for the supply of the raw material used in this study.

\section{References}

AACCI. (2010). Approved Methods of Analysis. AACC International.

ABINPET, B. I. A. of P. P. (2016). Market data of 2016 (p. 5). https://abinpet.org.br/site/mercado/

AOAC, association of official agricultural chemists. (2006). Official methods of analysis of the Association of Official Analytical Chemists (W. Howitz \& G. W. Latimer Jr (18th ed.). AOAC International.

Axelsson, E., Ratnakumar, A., Arendt, M.-L., Maqbool, K., Webster, M. T., Perloski, M., Liberg, O., Arnemo, J. M., Hedhammar, Å., \& Lindblad-Toh, K. (2013). The genomic signature of dog domestication reveals adaptation to a starch-rich diet. Nature, 495(7441), 360-364. https://doi.org/10.1038/nature11837

Biagi, G., Cipollini, I., Grandi, M., \& Zaghini, G. (2010). Influence of some potential prebiotics and fibre-rich foodstuffs on composition and activity of canine intestinal microbiota. Animal Feed Science and Technology, 159(1-2), 50-58. https://doi.org/10.1016/j.anifeedsci.2010.04.012

Brazil. (2008). Regulates and establishes procedures for the scientific use of animals (p. 20).

Byosiere, S.-E., Chouinard, P. A., Howell, T. J., \& Bennett, P. C. (2018). What do dogs (Canis familiaris) see? A review of vision in dogs and implications for cognition research. Psychonomic Bulletin \& Review, 25(5), 1798-1813. https://doi.org/10.3758/s13423-017-1404-7

Cauvain, S. (2015). Technology of Breadmaking. Springer International Publishing. https://doi.org/10.1007/978-3-319-14687-4

Chen, M., Chen, X., Cheng, W., Li, Y., Ma, J., \& Zhong, F. (2016). Quantitative optimization and assessments of supplemented tea polyphenols in dry dog food considering palatability, levels of serum oxidative stress biomarkers and fecal pathogenic bacteria. RSC Advances, 6(20), 16802-16807. https://doi.org/10.1039/C5RA22790A

Chevallier, S., Colonna, P., Buléon, A., \& Della-Valle, G. (2000). Physicochemical behaviors of sugars, lipids, and gluten in short dough and biscuit. Journal of Agricultural and Food Chemistry, 48(4), 1322-1326. https://doi.org/10.1021/jf990435+

Clerici, M. T. P. S., \& Carvalho-Silva, L. B. (2011). Nutritional bioactive compounds and technological aspects of minor fruits grown in Brazil. Food Research International, 44(7), 1658-1670. https://doi.org/10.1016/j.foodres.2011.04.020

Di Cerbo, A., Morales-Medina, J. C., Palmieri, B., Pezzuto, F., Cocco, R., Flores, G., \& Iannitti, T. (2017). Functional foods in pet nutrition: Focus on dogs and cats. Research in Veterinary Science, 112, 161-166. https://doi.org/10.1016/j.rvsc.2017.03.020

Dunlap, K. L., Reynolds, A. J., \& Duffy, L. K. (2006). Total antioxidant power in sled dogs supplemented with blueberries and the comparison of blood parameters associated with exercise. Comparative Biochemistry and Physiology Part A: Molecular \& Integrative Physiology, 143(4), 429-434. https://doi.org/10.1016/j.cbpa.2005.09.007

FEDIAF, F. européenne de l'industrie des aliments pour animaux familiers. (2019). Nutritional Guidelines for Complete and Complementary Pet Food for Cats and Dogs (p. 100).

Hall, J. A., Picton, R. A., Finneran, P. S., Bird, K. E., Skinner, M. M., Jewell, D. E., \& Zicker, S. (2006). Dietary antioxidants and behavioral enrichment enhance neutrophil phagocytosis in geriatric Beagles. Veterinary Immunology and Immunopathology, 113(1-2), 224-233. https://doi.org/10.1016/j.vetimm.2006.03.019

Hussein, H. S., Flickinger, E. A., \& Fahey, G. C. (1999). Petfood Applications of Inulin and Oligofructose. The Journal of Nutrition, 129(7), 1454S-1456S. https://doi.org/10.1093/jn/129.7.1454S

Knight, A., \& Leitsberger, M. (2016). Vegetarian versus Meat-Based Diets for Companion Animals. Animals, 6(9), 57. https://doi.org/10.3390/ani6090057

Kozłowska, I., Marć-Pieńkowska, J., \& Bednarczyk, M. (2016). 2. Beneficial Aspects of Inulin Supplementation as a Fructooligosaccharide Prebiotic in Monogastric Animal Nutrition - A Review. Annals of Animal Science, 16(2), 315-331. https://doi.org/10.1515/aoas-2015-0090

Li, D., Kim, J. M., Jin, Z., \& Zhou, J. (2008). Prebiotic effectiveness of inulin extracted from edible burdock. Anaerobe, 14(1), 29-34. https://doi.org/10.1016/j.anaerobe.2007.10.002

Manley, D. (2000). Technology of biscuits, crackers and cookies (D. Manley). CRC Press.

Mintel, G. L. (2018). US sales of pet treats outpace dog/cat food over the last five years (p. 5). https://www.mintel.com/press-centre/social-and-lifestyle/ussales-of-pet-treats-outpace-dogcat-food-over-the-last-five-years

Moro, T. M. A., Celegatti, C. M., Pereira, A. P. A., Lopes, A. S., Barbin, D. F., Pastore, G. M., \& Clerici, M. T. P. S. (2018). Use of burdock root flour as a prebiotic ingredient in cookies. LWT - Food Science and Technology, 90, 540-546. https://doi.org/10.1016/j.1wt.2017.12.059

Nabeshima, E. H., Moro, T. M. A., Campelo, P. H., Sant'Ana, A. S., \& Clerici, M. T. P. S. (2020). Tubers and roots as a source of prebiotic fibers. Advances in Food and Nutrition Research, 94. https://doi.org/10.1016/bs.afnr.2020.06.005

Oliveira, T. W. N. de, Damasceno, A. N. C., Oliveira, V. A. de, Silva, C. E. de O., Oliveira, V. M. A. de, Silva, R. K. dos S. e, Sousa, A. A. de, Sousa, C. B. de, Negreiros, H. A., Barros, N. V. dos A., Sousa, J. M. de C. e, Silva, F. C. C. da, \& Medeiros, S. R. A. (2020). Evaluation of the physical-chemical composition and hypoglycemic properties in biscuits produced with eggplant (Solanum melongena L.) and okra (Abelmoschus esculentus L. Moench). Research, Society and Development, 9(5), e41952712. https://doi.org/10.33448/rsd-v9i5.2712 
Research, Society and Development, v. 10, n. 2, e57510212987, 2021

(CC BY 4.0) | ISSN 2525-3409 | DOI: http://dx.doi.org/10.33448/rsd-v10i2.12987

Olivry, T., \& Bizikova, P. (2010). A systematic review of the evidence of reduced allergenicity and clinical benefit of food hydrolysates in dogs with cutaneous adverse food reactions. Veterinary Dermatology, 21(1), 32-41. https://doi.org/10.1111/j.1365-3164.2009.00761.x

Pereira, A. P. A., Clerici, M. T. P. S., Schmiele, M., \& Pastore, G. M. (2019). Blackberries (Rubus sp.) and whole grain wheat flour in cookies: evaluation of phenolic compounds and technological properties. Journal of Food Science and Technology, 56(3), 1445-1453. https://doi.org/10.1007/s13197-019-03628-6

Propst, E. L., Flickinger, E. A., Bauer, L. L., Merchen, N. R., \& Fahey, G. C. (2003). A dose-response experiment evaluating the effects of oligofructose and inulin on nutrient digestibility, stool quality, and fecal protein catabolites in healthy adult dogs. Journal of Animal Science, 81(12), 3057-3066. https://doi.org/10.2527/2003.81123057x

Re, R., Pellegrini, N., Proteggente, A., Pannala, A., Yang, M., \& Rice-Evans, C. (1999). Antioxidant activity applying an improved ABTS radical cation decolorization assay. Free Radical Biology and Medicine, 26(9-10), 1231-1237. https://doi.org/10.1016/S0891-5849(98)00315-3

Roberfroid, M. B. (2005). Introducing inulin-type fructans. British Journal of Nutrition, 93(S1), S13-S25. https://doi.org/10.1079/bjn20041350

Roberfroid, M. B. (2007). Inulin-Type Fructans: Functional Food Ingredients. The Journal of Nutrition, 137(11), 2493S-2502S. https://doi.org/10.1093/jn/137.11.2493S

Roesler, R., Catharino, R. R., Malta, L. G., Eberlin, M. N., \& Pastore, G. (2007). Antioxidant activity of Annona crassiflora: Characterization of major components by electrospray ionization mass spectrometry. Food Chemistry, 104(3), 1048-1054. https://doi.org/10.1016/j.foodchem.2007.01.017

Rofe, P. C., \& Anderson, R. S. (1970). Food preference in domestic pets. Proceedings of the Nutrition Society, 29(2), 330-335. https://doi.org/10.1079/PNS19700064

Sousa, R. S. de, Novais, T. S., Batista, F. O., \& Zuñiga, A. D. G. (2020). Análise sensorial de cookie desenvolvidos com farinha da casca de abacaxi (Ananas comosus (L.) Merril). Research, Society and Development, 9(4), e45942816. https://doi.org/10.33448/rsd-v9i4.2816

Strickling, J. ., Harmon, D. ., Dawson, K. ., \& Gross, K. . (2000). Evaluation of oligosaccharide addition to dog diets: influences on nutrient digestion and microbial populations. Animal Feed Science and Technology, 86(3-4), 205-219. https://doi.org/10.1016/S0377-8401(00)00175-9

Wang, S. Y., \& Lin, H.-S. (2000). Antioxidant Activity in Fruits and Leaves of Blackberry, Raspberry, and Strawberry Varies with Cultivar and Developmental Stage. Journal of Agricultural and Food Chemistry, 48(2), 140-146. https://doi.org/10.1021/jf9908345 